\title{
MODEL PROBLEM BASED LEARNING (PBL) DENGAN PENDEKATAN SCIENCE TECHNOLOGY ENGINEERING MATHEMATICS (STEM) DALAM PEMBELAJARAN FISIKA MATERI ELASTISITAS DI KELAS XI MIPA 4 SMA NEGERI 2 JEMBER
}

\author{
${ }^{1)}$ Mita Dwi Agustin, ${ }^{1)}$ Albertus Djoko Lesmono, ${ }^{1)}$ Heny Mulyo Widodo \\ ${ }^{1)}$ Program Studi Pendidikan Fisika FKIP Universitas Jember \\ Email: mitadwiagustin@gmail.com
}

\begin{abstract}
The Problem Based Learning (PBL) model has been applied in Indonesia for a long time. The Problem Based Learning (PBL) model with the approach of Science, Technology, Engineering, and Mathematics (STEM) is new in the world of education. When students are introduced to the new learning model, it will make students have a high curiosity and a great desire to learn. Having a great desire to learn will affect student learning outcomes. Problem Based Learning (PBL) model with the approach of Science, Technology, Engineering, and Mathematics (STEM) is expected to improve student learning outcomes in the cognitive domain. This study aims to describe student learning outcomes using the Problem Based Learning $(P B L)$ model which is integrated with Science, Technology, Engineering, and Mathematics (STEM) on the subject of elasticity. This type of research is a true experimental research design with pretest-posttest control-design conducted in class XI MIPA 4. The conclusion of this study is the Problem Based Learning (PBL) model with the approach of Science, Technology, Engineering, and Mathematics (STEM) can improve student learning outcomes in the cognitive domain in learning physics in class XI MIPA 4 SMA NEGERI 2 JEMBER.
\end{abstract}

Keywords: Problem Based Learning, STEM, and Student Learnig Outcomes.

\section{PENDAHULUAN}

Pesatnya perkembangan Ilmu pengetahuan dan teknologi, ditambah dengan implementasi penyempurnaan kurikulum yang belum dipahami oleh para pelaku pendidikan menjadi penyebab kondisi pendidikan IPA (sains) di Indonesia masih sangat memprihatinkan. Pembelajaran IPA (sains) lebih menekankan untuk mengingat konsep. STEM merupakan akronim dari Science, Technology, Engineering, dan Mathematics pertama kali diluncurkan oleh National Science Foundation Amerika Serikat pada tahun 1990-an untuk mengembangkan warga negara yang paham akan STEM (STEM literate), serta meningkatkan daya saing global Amerika Serikat (AS) dalam inovasi IPTEK (Rustaman, dkk. 2016 : 1). Penguasaan Ilmu Pengetahuan dan Teknologi (IPTEK) saat ini menjadi kunci menghadapi tantangan di masa depan. Berbagai tantangan yang muncul antara lain berkaitan dengan peningkatan kualitas hidup dan kemampuan untuk mengembangkan sumber daya manusia. Pendidikan IPA (sains) sebagai bagian dari pendidikan berperan penting untuk menyiapkan 
peserta didik yang memiliki literasi sains, yaitu yang mampu berpikir kritis, kreatif, logis, dan berinisiatif dalam menanggapi isu di masyarakat yang diakibatkan oleh dampak perkembangan IPA dan teknologi. Pendidikan IPA (sains) diharapkan dapat menjadi wahana bagi peserta didik untuk mempelajari alam sekitar, serta prospek pengembangan lebih lanjut dalam menerapkannya di dalam kehidupan sehari-hari (Permanasari, 2016 : 23). Berdasarkan hasil laporan puspendik kemdikbud (2019), rata-rata nilai Ujian Nasional tingkat SMA/MA untuk program studi IPA (Fisika) memiliki nilai rata-rata 55.31 (2016), 49.57 (2017), dan 44.22 (2018). Ratarata nilai Ujian Nasional tersebut menunjukan bahwa tidak ada peningkatan nilai fisika setiap tahunnya. Terdapat beberapa faktor yang menyebabkan nilai fisika terus menerus menurun. Faktor pertama yang sangat berpengaruh adalah siswa tidak mau belajar fisika yang disebabkan fisika terlalu sulit atau model pembelajaran yang digunakan terkesan membosankan. Sehingga tidak dapat menarik minat siswa untuk belajar fisika. Peneliti menerapakan model Problem Based Learning (PBL) dengan pendekatan Science, Technology, Engineering, dan Mathematics (STEM) yang diharapkan dapat meningkatkan hasil belajar siswa di SMA. Problem Based Learning (PBL) adalah metode pengajaran yang memiliki permasalahan nyata untuk para siswa belajar berpikir kritis dan memiliki keterampilan memecahkan masalah (Duch,1995). Pembelajaran STEM merupakan integrasi dari pembelajaran sains, teknologi, teknik, dan matematika yang disarankan untuk membantu kesuksesan berketerampilan (Beers, 2011). Tujuan dari Science, Technology, Engineering, dan Mathematics (STEM) adalah untuk menghasilkan siswa yang ketika terjun di masyarakat, mereka mampu mengembangkan kompetensi yang telah dimiliki untuk mengaplikasikannya pada berbagai situasi dan permasalahan yang mereka hadapi di kehidupan sehari-hari (Mayasari et al, 2014). Science, Technology, Engineering, dan Mathematics (STEM) dapat berkembang apabila dikaitkan dengan lingkungan, sehingga terwujud sebuah pembelajaran yang menghadirkan dunia nyata yang dialami siswa dalam kehidupan sehari-hari (Subramaniam et al, 2012). Penerapan Science, Technology, Engineering, dan Mathematics (STEM) dalam pembelajaran dapat mendorong peserta didik untuk mendesain, mengembangkan dan memanfaatkan teknologi, mengasah kognitif, manipulatif dan afektif, serta mengaplikasikan pengetahuan (Kapila, et all. 2014. 46-51). Berdasarkan permasalahan tersebut sangat menarik diteliti pembelajaran yang dapat membantu siswa dalam meningkatkan hasil belajar. Tujuan dari penelitian ini adalah untuk mendeskripsikan pengaruh model pembelajaran Problem Based Learning (PBL) dangan pendekatan Science, Technology, Engineering, dan Mathematics (STEM) terhadap hasil belajar siswa. 


\section{METODE PENELITIAN}

Jenis penelitian yang digunakan adalah penelitian true eksperimen dengan desain pretest-posttest controldesign. Penelitian ini dilaksanakan di kelas XI MIPA 4 pada materi elastisitas. Waktu penelitian pada bulan September 2019 bertempat di SMA NEGERI 2 JEMBER. Teknik penggumpulan data yang digunakan dengan cara memberikan pretest kepada siswa sebelum pembelajaran dan memberikan posttest kepada siswa setelah pembelajaran selesai. Hasil belajar yang diukur dalam penilitian ini yaitu hasil belajar kognitif yang di tinjau dari nilai pretest dan posttest yang telah didapat. Siswa dikatakan tuntas dalam belajar jika nilai yang didapatkan sesuai dengan nilai KKM yang telah ditetapkan yaitu $\geq 80$. Peningkatan hasil belajar siswa setelah menggunakan model PBL dengan pendektan Science, Technology, Engineering, dan Mathematics (STEM) diperoleh dengan menghitung menggunakan rumus N-Gain. Rumus N-Gain yaitu :

$$
N-\text { Gain }=\frac{\left(S_{\text {post }}-S_{\text {pre }}\right)}{\left(S_{\text {maks }}-S_{\text {pre }}\right)}
$$

Keterangan :

$N-$ Gain $=$ Normalized Gain

$S_{\text {pre }}=$ Skor rata-rata seluruh siswa sebelum menggunakan model PBL dengan pendeketan STEM

$S_{\text {post }}=$ Skor rata-rata seluruh siswa sesudah menggunakan model PBL dengan pendeketan STEM

$S_{\text {maks }}=$ Skor maksimal (tertinggi) yang diperoleh

(Latief, $2014:$ 19)
Kriteria peningkatan hasil belajar kognitif siswa dapat dilihat pada Tabel 1.

Tabel 1. Kriteria peningkatan hasil belajar

\begin{tabular}{|c|c|}
\hline Nilai N-Gain & Kriteria \\
\hline N-Gain $\geq 0.7$ & Tinggi \\
\hline $0.3 \leq$ N-Gain $<0.7$ & Sedang \\
\hline N-Gain $<0.3$ & Rendah \\
\hline \multicolumn{2}{|c|}{ (Liliawati, 2010 : 427) }
\end{tabular}

\section{HASIL DAN PEMBAHASAN}

Pada penelitian ini, peneliti membandingkan nilai pada saat mengajar sebelum dan setelah menggunakan model Problem Based Learning (PBL) dengan pendekatan Science, Technology, Engineering, dan Mathematics (STEM). Hasil belajar siswa sebelum maupun sesudah menggunakan model Problem Based Learning (PBL) dengan pendekatan Science, Technology, Engineering, dan Mathematics (STEM) adalah sangat baik. Data hasil rata-rata belajar siswa dapat dilihat pada Tabel2.

Tabel 2. Ringkasan nilai pretest dan posttest

\begin{tabular}{ccc}
\hline Nilai & Sebelum & Sesudah \\
\hline Nilai rata-rata & 97.62 & 99.14 \\
\hline Nilai tertinggi & 100 & 100 \\
\hline Nilai terendah & 80 & 90 \\
\hline
\end{tabular}

Selain meninjau dari hasil belajar kognitif siswa, peniliti menyebarkan angket kepada siswa kelas XI MIPA 4 untuk memperkuat hasil dari penelitian. Hasil dari angket yang telah disebarkan kepada siswa, 57.14\% siswa menyukai model pembelajaran Problem Base Learning (PBL) dengan pendekatan Science, Technology, Engineering, dan Mathematics (STEM), $68.57 \%$ membaca materi pelajaran sebelum pelajaran dimulai, $60 \%$ siswa menjadi aktif bertanya pada 
saat menggunakan model pembelajaran Problem Base Learning (PBL) dengan pendekatan Science, Technology, Engineering, dan Mathematics (STEM) karena siswa memiliki rasa ingin tahu yang tinggi.

Hasil belajar siswa yang telah diperoleh di analisis oleh peneliti menggunakan rumus N-Gain sebagai berikut.

$$
\begin{gathered}
N-\text { Gain }=\frac{(99.14-97.62)}{(100-97.62)}=\frac{1.52}{2.38} \\
=0.63
\end{gathered}
$$

Hasil yang diperoleh adalah 0.63. Jadi hasil belajar siswa mengalami peningkatan yang sedang. Hal ini dibuktikan dengan meninjau tabel kriteria peningkatan hasil belajar siswa. Nilai N-Gain 0.63 berada dalam tingkatan yang sedang. Sehingga dapat dikatakan bahwa model pembelajaran Problem Based Learning (PBL) dengan pendekatan Science, Technology, Engineering, dan Mathematics (STEM) dapat meningkatkan hasil belajar siswa.

Peningkatan yang dihasilkan memang tidak terlalu tinggi, dikarenakan siswa kelas XI SMA NEGERI 2 JEMBER adalah siswa yang pintar dan cerdas. Siswa kelas XI adalah siswa yang terpilih melalui jalur tes tulis. Sehingga, mereka memiliki kemampuan yang cukup baik dalam bidang akademik. Dalam menggunakan model pembelajaran apapun mereka mampu menguasi materi yang diberikan oleh guru. Namun, pada saat guru menggunakan model pembelajaran Problem Based Learning (PBL) dengan pendekatan Science, Technology, Engineering, dan Mathematics (STEM) mampu meningkatan hasil belajar siswa, jadi dapat dikatakan penelitian ini berhasil. Peningkatan hasil belajar siswa dikarenakan model Problem Based Learning (PBL) dengan pendekatan Science, Technology, Engineering, dan Mathematics (STEM). Hal ini diperkuat dengan hasil angket dari siswa bahwa siswa menjadi sangat aktif dalam bertanya pada saat proses pembelajaran terkait hal-hal yang masih belum siswa pahami, siswa memiliki minat belajar yang tinggi karena siswa menyukai model pembelajaran Problem Based Learning (PBL) dengan pendekatan Science, Technology, Engineering, dan Mathematics (STEM) yang baru saja diajarkan kepada mereka.

\section{SIMPULAN DAN SARAN}

Bedasarkan hasil analisis data yang diperoleh model pembelajaran Problem Based Learning (PBL) dengan pendekatan Science, Technology, Engineering, dan Mathematics (STEM) dapat meningkatkan hasil belajar siswa pada ranah kognitif dalam pembelajaran fisika di kelas XI MIPA 4 SMA NEGERI 2 JEMBER.

\section{DAFTAR PUSTAKA}

Duch. 1995. Pembelajaran Berbasis Masalah. Jakarta: Sejarah Indonesia.

Kapila, V. \& Iskander, M. 2014. Lessons learned from conducting a K12 project to revitalize achievement by using instrumentation in Science 
Education. Journal of STEM Education. 15(1). Hal 46-51.

Latief, Hilman, dkk. 2014. PENGARUH

PEMBELAJARAN

KONTEKSTUAL TERHADAP HASIL BELAJAR. Jurnal Gea. 14(1). Hal 19.

Mayasari, T., Kadarohman, A., \& Rusdiana, D. 2014. Pengaruh Pembelajaran Terintegrasi Science, Technology, Engineering, And Mathematics (STEM) Pada Hasil Belajar Peserta Didik: Studi Meta Analisis. Prosiding Semnas Pensa VI "Peran Literasi Sains". 371-377.

Permanasari, Anna. 2016. STEM Education: Inovasi dalam Pembelajaran Sains. Prosiding Seminar Nasional Pendidikan Sains (SNPS). Hal 23.
Puspendik, kemdikbud. Laporan Hasil Ujian Nasional. http://puspendik.kemdikbud.go.i d/hasil-un/ (diakses 8 September 2019).

Rustaman, Nuryani, dkk. 2016. Pembelajaran Masa Depan Melalui Stem Education. Prosiding Seminar Nasional Biologi Edukasi 2016. ISBN: 978-602-74224-1-4. Hal 1-2.

Subramaniam, M. M., Ahn, J., Fleischman, K. R., \& Druin, A. 2012. Reimagining the role of school libraries in STEM education: Creating hybrid spaces for exploration. The Library Quarterly. 82(2): 161182. 